\title{
Eksperimentasi Mobile Learning Pada Mata Kuliah Kalkulus Integral Ditinjau Dari Kemampuan Bekerjasama
}

\author{
Siti Suprihatiningsih ${ }^{1^{*}}$, Nugroho Arif Sudibyo ${ }^{2}$, Triana Harmini ${ }^{3}$ \\ 1Pendidikan Matematika, STKIP Pamane Talino, Landak, Indonesia; \\ *s.suprihatiningsih@stkippamanetalino.ac.id \\ 2 Teknik Informatika, Universitas Duta Bangsa, Surakarta, Indonesia; \\ nugroho arif@udb.ac.id \\ ${ }^{3}$ Teknik Informatika, Universitas Darrusalam, Ponorogo, Indonesia; \\ triana@unida.gontor.ac.id
}

\begin{abstract}
Abstrak. Masa pandemi covid-19 seperti saat ini mengharuskan untuk mencari alternatif pembelajaran yang efektif digunakan. Pembelajaran biasanya tatap muka langsung sekarang melalui daring. Salah satu alternatif dalam pembelajaran saat ini adalah penggunaan smartphone atau biasa disebut dengan mobile learning. Penelitian ini bertujuan untuk mengetahui: 1) perbedaan prestasi belajar matematika mahasiswa dengan pembelajaran melalui mobile learning dan google classroom, 2) interaksi antara pembelajaran melalui mobile learning dan kemampuna bekerja sama mahasiswa terhadap prestasi belajar matematika , 3) perbedaan prestasi belajar matematika mahasiswa pada tingkat kemampuan bekerja sama. Subjek penelitian ini adalah mahasiswa Program Studi Pendidikan Matematika STKIP Pamane Talino yang mengambil mata kuliah Kalkulus Integral sebanyak 68 mahasiswa yang terdiri dari 2 kelas. Pelaksanaan penelitian berlangsung selama 5 kali pertemuan. Setiap kelompok diajar dengan materi yang sama. Instrumen dalam penelitian ini berupa instrumen tes dan angket (kuisioner). Metode penelitian menggunakan quasi eksperimen dengan pendekatan desain factorial 2x3. Uji analisis data yang digunakan yaitu uji ANAVA dua jalur dengan prasyarat analisis berupa uji normalitas dan uji homogenitas. Hasil analisi data menunjukkan bahwa data berdistribusi normal dan homogen, sehingga dapat disimpulkan bahwa : (1) pembelajaran dengan media Mobile Learning lebih efektif daripada pembelajaran dengan media Google Classroom, (2) tingkat kemampuan bekerja sama tinggi,sedang dan rendah memberikan efek yang berbeda terhadap prestasi belajar matematika mahasiswa dan (3) pengaruh penggunaan media pembelajaran mobile learning dan google classroom terhadap prestasi belajar tidak bergantung kepada kemampuan kerjasama mahasiswa. Sebaliknya pengaruh kemampuan kerjasama mahasiswa, terhadap prestasi belajar tidak bergantung kepada penggunaan media pembelajaran, baik melalui mobile learning atau google classroom.
\end{abstract}

Kata Kunci: Mobile Learning, kemampuan Bekerja sama, Kalkulus Integral 
Abstract. The covid-19 pandemic period like now requires finding alternative learning that is effectively used. It drives a changing method of learning from face-toface to online. One alternative in learning today is the use of smartphones or commonly referred to as mobile learning. This study aims to determine: 1) differences in student mathematics learning achievement with learning through mobile learning and google classroom, 2) interaction between learning through mobile learning and the ability to work together with students towards mathematics learning achievement, 3) differences in student mathematics learning achievement at the level of ability cooperate. The subjects of this study were students of the Mathematics Education Study Program STKIP Pamane Talino who took 68 Integral Calculus courses consisting of 2 classes. The research was conducted in 5 meetings. Each group was taught with the same material. The instruments in this study were tests and questionnaires. The research method used was quasi-experiment with a $2 \times 3$ factorial design approach. The data analysis test used was the two-way ANAVA test with the analysis prerequisites in the form of a normality test and a homogeneity test. The results of the data analysis show that the data are normally distributed and homogeneous. Thus, it can be concluded that: (1) learning with Mobile Learning media is more effective than learning with Google Classroom media, (2) the level of ability to work together with high, medium and low gives different effects on student mathematics learning achievements and (3) the effect of the use of mobile learning media and google classroom learning on learning achievement does not depend on the ability of student collaboration. On the other hand, the effect of student collaboration ability on learning achievement does not depend on the use of learning media, either through mobile learning or google classroom.

Keywords: Mobile Learning, Cooperation skills, Integral Calculus

\section{Pendahuluan}

Kalkulus integral merupakan salah satu mata kuliah wajib yang diajarkan pada semester II program studi pendidikan matematika STKIP Pamane Talino. Kondisi pandemi covid-19 seperi saat ini tidak memungkinkan pembelajaran secara tatap muka. Inovasi pembelajaran secara daring mulai bermunculan, mulai dari penggunaan aplikasi zoom, whatsapps maupun google classroom. Pembelajaran daring juga memaksimalkan fungsi Smartphone, yang semula hanya digunakan untuk berkomunikasi dan bermain sekarang mulai digunakan untuk belajar (Nugroho \& Purwati, 2015). Kemajuan Teknologi Informasi dan Komunikasi di bidang pendidikan pada penggunaan media pembelajaran yang ditandai dengan munculnya konsep Electronic Learning (e-learning)(Nuryadi, 2019). Smartphone dengan operasi sistem (OS) android sekarang banyak dimiliki mahasiswa. Pada OS android kebanyakan dimanfaatkan untuk game, facebook, twitter, whatapps, BBM namun dengan kondisi pandemi yang tidak memungkinkan pembelajaran 
dengan tatap muka langsung di kelas, memberi peluang untuk dosen untuk menerapkan pembelajaran berbasis mobile atau mobile learning.

Perkembangan teknologi menjadikan kebutuhan pembelajaran berbasis TI tidak dapat dihindari. Perkembangan seperti ini biasa disebut dengan e-learning. Salah satu jenis e-learning yaitu pembelajaran berbasis mobile atau biasa disebut mobile learning(Ramadan \& Arfinanti, 2019). Mobile learning merupakan salah satu pemanfaatan teknologi informasi dan komunikasi untuk media pembelajaran yang bersifat interaktif dalam proses pembelajaran, sehingga proses belajar siswa dapat menarik dan tidak terbatas oleh ruang dan waktu.. Selain itu konten yang ada kebanyakan masih bersifat hiburan dan belum banyak dimanfaatkan untuk pembelajaran(Yuliani, 2010).

Attwell dalam International Journal of Mobile and Blended Learning menyatakan tujuan pengenalan sistematis penggunaanmobile learning yang menarik untuk mengeksplorasi penggunaan perangkat mobile dalam belajar (Attwell, 2010). Penggunaan mobile learning dalam pembelajaran matematika memiliki beberapa keunggulan, diantaranya 1) dapat dioperasikan dimanapun dan kapanpun, 2) meningkatkan motivasi mahasiswa, dan 3) meningkatkan pembelajaran sesuai kebutuhan mahasiswa(Setyadi, 2017).

Proses pembelajaran matematika selama ini menggunakan model pembelajaran konvensional yang membutuhkan tatap muka di kelas. Dosen mengajar menggunakan metode teacher centered learning dimana peran dosen sangat dominan selama pembelajaran. Hal ini menyebabkan peserta didik hanya menyerap informasi, menghafal, dan mencatat dari penjelasan materi yang diberikan dosen. Peserta didik tidak dituntut memahami materi, mengungkapkan ide, dan memecahkan masalah matematika. Peran dosen yang sangat dominan menyebabkan sikap kurang mandirinya mahasiswa.

STKIP Pamane Talino sebagai lembaga pendidikan yang menghasilkan calon guru atau calon tenaga pengajar sangat diharapkan untuk dapat mengikuti perkembangan teknologi dan kebutuhan dalam dunia kerja. Pada lingkungan kerja sekarang ini kemampuan bekerja sama sangat diperlukan dalam menyelesaikan suatu masalah atau pekerjaan. Sebagai calon guru, mahasiswa harus mempunyai kemampuan bekerja sama agar dapat menyampaikan materi yang bermakna kepada siswanya kelak.

Kemampuan bekerja sama merupakan kemampuan yang harus dimiliki mahasiswa, dengan kemampuan ini mahasiswa dapat saling memahami

Copyright (C) 2020

Buana Matematika :

Jurnal Ilmiah Matematika dan Pendidikan Matematika 
orang lain dan dapat menyelesaikan permasalahan. Kekhawatiran timbul saat pembelajaran melalui daring, komunikasi antar mahasiswa jadi terbatas bahkan tidak ada. Komunikasi terjadi antara dosen dengan mahasiswa secara personal karena kondisi wabah covid-19 yang tidak memungkinkan mahasiswa untuk berkelompok dalam sebuah tim saat pembelajaran.

Kemampuan bekerja sama sangat penting dimiliki mahasiswa. Bekerja sama merupakan sifat sosial manusia dan bagian penting yang tidak dapat dihindari dari kehidupan (Wulandari, Arifin, \& Irmawati, 2015). Kemampuan bekerja sama merupakan salah satu unsur agar tujuan pembelajaran dapat tercapai (Marcella, Wulanata, \& Listiani, 2018). Mahasiswa akan terlatih dengan bekerja sama karena pembelajaran di kelas sudah dibiasakan. Selain di kelas mahasiswa diharapkan dapat menerapkan kemampuan bekerja sama dalam kehidupan sehari-hari(Anton, Kusno, \& Fitrianto, 2013). Dengan demikian pembelajaran matematika memiliki fungsi sebagai sarana untuk mengembangkan kemampuan berpikir kritis, kreatif dan bekerja sama yang diperlukan siswa dalam kehidupan modern(Atikasari, Agoestanto, \& Winanti, 2018).

Bekerja sama dalam pembelajaran dapat diartikan sebagai sikap atau perilaku dalam hubungan antar peserta didik untuk saling membantu sesama teman dalam kerja kelompok(Suhardi, 2013). Indikator kemampuan bekerja sama berdasar pendapat Maasawet yaitu: 1) memberi informasi kepada sesama anggota kelompok, 2) dapat membantu menyelesaikan perselisihan yang terjadi, 3) dapat menciptakan suasana bekerja sama yang akrab, 4) bertukar ide dan pendapat kepada anggota kelompok, 5) mendukung keputusan kelompok, 6) menghargai masukan dan keahlian anggota lain, 7) berpartisipasi melaksanakan tugas, 8) menghargai hasil kerja kelompok (Maasawet, 2011). Aspek kemampuan bekerja sama dalam pembelajaran menurut Pratiwi dkk adalah peningkatan kemampuan bekerja sama siswa dalam aspek: 1) kebersamaan menyelesaikan tugas proyek, 2) mendiskusikan perencanaan proyek dengan tepat, 3) saling tukar pendapat, dan 4) kekompakan dalam menyelesaikan tugas proyek (Pratiwi, Ardianti, \& Kanzunnudin, 2018). Dalam penelitian ini, indikator kemampuan bekerja sama mahasiswa yang akan dikembangkan antara lain: 1) saling memberi informasi, 2) menghargai pendapat orang lain, 3) saling diskusi dalam penyelesaian tugas, 4) berpartisipasi aktif dalam penyelesaian tugas, dan 5) kekompakan dalam menyelesaikan tugas. 
Tujuan penelitian ini yaitu untuk 1) mengkaji perbedaan prestasi belajar matematika mahasiswa dengan pembelajaran melalui mobile learning dan google classroom, 2) interaksi antara pembelajaran melalui mobile learning dan kemampuna bekerja sama mahasiswa terhadap prestasi belajar matematika , 3) perbedaan prestasi belajar matematika mahasiswa pada tingkat kemampuan bekerja sama.

\section{Metode}

Penelitian ini merupakan penelitian eksperimental semu dengan desain faktorial 2x3. Variabel penelitian ini berupa variabel bebas dan variabel terikat. Variabel bebas dalam penelitian ini adalah media pembelajaran mobile learning dan google classroom serta kemampuan bekerja sama mahasiswa yang terbagi dalam tiga tingkatan yaitu tinggi, sedang, dan rendah. Variabel terikat dalam penelitian ini adalah prestasi belajar mahasiswa pada materi integral. Penelitian ini melibatkan dua kelompok, yaitu satu kelompok diajar menggunakan mobile learning dan satu kelompok diajar menggunakan google classroom. Subjek dalam penelitian ini adalah mahasiswa Program Studi Pendidikan Matematika STKIP Pamane Talimo yang terdiri dari dua kelas yang berjumlah 68 mahasiswa. Penelitian ini dilaksanakan pada semester ganjil tahaun ajaran 2019/2020 pada materi Kalkulus Integral. Pelaksanaan penelitian berlangsung selama 5 kali pertemuan. Setiap kelompok diajar dengan materi yang sama.

Instrumen dalam penelitian ini berupa instrumen tes dan angket (kuisioner). Instrumen tes digunakan untuk mengukur prestasi belajar mahasiswa dan angket digunakan untuk mengukur kemampuan bekerja sama mahasiswa. Instrumen tes yang digunakan berupa tes essay yang terdiri dari 5 soal yang diberikan kepada mahasiswa pada akhir pembelajaran. Instrumen angket disusun berdasarkan 5 indikator kemampuan bekerja sama terdiri dari 15 pertanyaan tertutup dengan 5 pilihan jawaban yaitu Sangat Setuju (5), Setuju (4), Ragu-ragu (3), Tidak Setuju (2), dan Sangat Tidak Setuju (1). Kemampuan bekerja sama dalam penelitian ini sebagai variabel terikat. Instrumen tes dan angket sebelum digunakan dalam penelitian telah dilakukan validasi dengan dosen matematika untuk mengetahui kesesuaian soal tes dan indikator kemampuan bekerja sama.

Pengumpulan data prestasi belajar mahasiswa dilakukan dengan menggunakan instrumen tes yang diberikan pada akhir pembelajaran materi Integral. Data yang diperoleh berupa skor tes mahasiswa yang kemudian akan dianalisis. Data kemampuan bekerja sama mahasiswa diperoleh dengan

Copyright (C) 2020

Buana Matematika :

Jurnal Ilmiah Matematika dan Pendidikan Matematika 
menggunakan angket kemampuan bekerja sama. Data kemampuan bekerja sama mahasiswa digunakan untuk pengelompokkan tingkat kemampuan bekerja sama mahasiswa yaitu tinggi, sedang, dan rendah. Pedoman pengkategoriannya sesuai dengan Tabel 1.

Tabel 1. Pedoman Acuan Norma Pengkategorian Tingkat Kemampuan Bekerja Sama Mahasiswa

\begin{tabular}{ccc}
\hline No. & Skor & Kategori \\
\hline 1 & Skor $<\bar{X}-0,5 \mathrm{SD}$ & Rendah \\
2 & $\bar{X}-0,5 \mathrm{SD} \leq$ Skor $\leq \bar{X}+0,5$ SD & Sedang \\
3 & Skor $>0,5 \mathrm{SD}+\bar{X}$ & Tinggi \\
\hline
\end{tabular}

Keterangan:

Skor : rata-rata skor angket kemampuan bekerja sama mahasiswa

$\bar{X} \quad$ : nilai rata-rata total

SD : Standar deviasi total

Teknik analisis data yang digunakan dalam penelitian ini adalah uji ANAVA dua jalur. Penelitian ini menggunakan rancangan faktorial $2 \times 3$ untuk mengetahui pengaruh dua variabel bebas terhadap variabel terikat. Rancangan penelitian ini disajikan pada Tabel 2.

Tabel 2. Rancangan Penelitian

\begin{tabular}{cccc}
\hline Media Pembelajaran & \multicolumn{3}{c}{ Kemampuan bekerja sama $(\mathrm{B})$} \\
$(\mathrm{A})$ & tinggi $\left(\mathrm{b}_{1}\right)$ & sedang $\left(\mathrm{b}_{2}\right)$ & rendah $\left(\mathrm{b}_{3}\right)$ \\
\hline Mobile learning (a1) & $\mathrm{ab}_{11}$ & $\mathrm{ab}_{12}$ & $\mathrm{ab}_{13}$ \\
Google classroom $\left(\mathrm{a}_{2}\right)$ & $\mathrm{ab}_{21}$ & $\mathrm{ab}_{22}$ & $\mathrm{ab}_{23}$ \\
\hline
\end{tabular}

Keterangan:

$\mathrm{ab}_{11}$

= Prestasi belajar mahasiswa dengan kemampuan bekerja sama tinggi yang diberi perlakuan pembelajaran melalui mobile learning.

$\mathrm{ab}_{12}$

= Prestasi belajar mahasiswa dengan kemampuan bekerja sama sedang yang diberi perlakuan pembelajaran melalui mobile learning. 


\begin{abstract}
$\mathrm{ab}_{13}$
= Prestasi belajar mahasiswa dengan kemampuan bekerja sama rendah yang diberi perlakuan pembelajaran melalui mobile learning.

$\mathrm{ab}_{21}$

$=$ Prestasi belajar mahasiswa dengan kemampuan bekerja sama tinggi yang diberi perlakuan pembelajaran melalui google classroom.

$\mathrm{ab}_{22}$

= Prestasi belajar siswa dengan kemampuan bekerja sama sedang yang diberi perlakuan pembelajaran melalui google classroom.

$\mathrm{ab}_{23}$

= Prestasi belajar siswa dengan kemampuan bekerja sama rendah yang diberi perlakuan pembelajaran melalui google classroom.
\end{abstract}

Prasyarat analisis yang digunakan berupa uji normalitas dan uji homogenitas . Uji normalitas menggunakan uji Kolmogorov Smirnov dan uji homogenitas menggunakan uji Levene test. Semua analisis data menggunakan IBM SPSS Statistic 20.

\title{
Hasil dan Pembahasan
}

Penelitian ini dilakukan pada mahasiswa Program Studi Pendidikan Matematika STKIP Pamane Talino yang mengambil mata kuliah Kalkulus Integral. Data yang diperoleh pada penelitian berupa data kemampuan bekerja sama mahasiswa dan prestasi belajar mahasiswa. Data kemampuan bekerja sama mahasiswa digunakan untuk untuk pengelompokkan tingkat kemampuan bekerja sama mahasiswa yaitu tinggi, sedang, dan rendah. Hasil pengkategorian kemampuan bekerja sama mahasiswa disajikan pada Tabel 3.

Tabel 3. Data Jumlah Mahasiswa Berdasarkan Kemampuan Bekerja Sama

\begin{tabular}{|c|c|c|c|c|}
\hline \multirow[b]{2}{*}{ Media Pembelajaran } & \multicolumn{3}{|c|}{ Jumlah Mahasiswa } & \multirow{2}{*}{$\begin{array}{c}\text { Total } \\
\text { mahasisw } \\
\mathrm{a} \\
\end{array}$} \\
\hline & Tinggi & Sedang & Rendah & \\
\hline Mobile Learning & 12 & 13 & 7 & 32 \\
\hline Google classroom & 3 & 21 & 12 & 36 \\
\hline Jumlah Total & 15 & 34 & 19 & 68 \\
\hline
\end{tabular}

Dari Tabel 3 dapat diketahui bahwa sebanyak 34 orang mahasiswa mempunyai kemampuan bekerja sama pada kategori sedang. Hal ini menunjukkan bahwa dari hasil pembelajaran mata kuliah Kalkulus Integral pada materi integral memberikan dampak yang positif untuk kemampuan bekerja sama mahasiswa. Pada pembelajaran melalu mobile learning, jumlah

Copyright (C) 2020

Buana Matematika :

Jurnal Ilmiah Matematika dan Pendidikan Matematika 
mahasiswa dengan kemampuan bekerja sama tinggi sebanyak 12 orang sedangkan melalui media google classroom sebanyak 3 orang. Hal ini menunjukkan bahwa dengan menggunakan media mobile learning kemampuan bekerja sama mahasiswa lebih baik dibandingkan kemampuan bekerja sama mahasiswa dengan menggunakan media google classroom.

Data prestasi belajar matematika mahasiswa diperoleh dari hasil tes yang diberikan pada akhir pembelajaran. soal tes untuk kedua kelas baik kelas dengan media mobile laerning maupun kelas dengan media google classroom sama. Data prestasi belajar matematika mahasiswa ini digunakan untuk mengetahui perbedaan prestasi belajar mahasiswa dengan media mobile laerning dan media google classroom. Analisis deskriptif statistik data prestasi belajar matematika mahasiswa dengan media mobile learning dan google classroom disajikan pada Tabel 4.

Tabel 4. Analisis Deskriptif Statistik data prestasi belajar matematika mahasiswa

\begin{tabular}{llccc}
\hline Model & Kategori & Mean & Std.Deviation & $\mathrm{N}$ \\
\hline Google & Rendah & 66,75 & 8,114 & 12 \\
Classroom & Sedang & 73,86 & 4,912 & 21 \\
& Tinggi & 80,33 & 5,774 & 3 \\
& Total & $\mathbf{7 2 , 0 3}$ & $\mathbf{7 , 3 3 9}$ & $\mathbf{3 6}$ \\
\hline Mobile & Rendah & 71,71 & 4,192 & 7 \\
Learning & Sedang & 79,08 & 3,968 & 13 \\
& Tinggi & 87,75 & 4.07 & 12 \\
& Total & $\mathbf{8 0 , 7 2}$ & $\mathbf{7 , 3 4 5}$ & $\mathbf{3 2}$ \\
\hline Kemampuan & Rendah & 68,58 & 7,221 & 19 \\
Bekerja Sama & Sedang & 75,85 & 5,194 & 34 \\
& Tinggi & 86,27 & 5,216 & 15 \\
& Total & $\mathbf{7 6 , 1 2}$ & $\mathbf{8 , 4 9 7}$ & $\mathbf{6 8}$ \\
\hline
\end{tabular}

Pada Tabel 4 dapat diketahui bahwa rata-rata hasil prestasi belajar mahasiswa dengan menggunakan media mobile learning lebih baik daripada menggunakan media google classroom. Pada tingkat kemampuan bekerja sama mahasiswa kategori tinggi memiliki rata-rata prestasi belajar matematika paling tinggi. Untuk mengetahui signifikansi perbedaan prestasi belajar pada masing-masing kelompok dilakukan uji ANAVA dua jalur sel tak sama dengan prasyarat analisis berupa uji normalitas dan uji homogenitas.

Uji normalitas data dilakukan dengan menggunakan uji Shapiro-Wilk dengan taraf signifikansi 5\%. Uji normalitas dilakukan pada masing-masing Copyright $@ 2020$

\section{Buana Matematika :}

Jurnal Ilmiah Matematika dan Pendidikan Matematika 
kelompok media pembelajaran dan kelompok kemampuan bekerja sama mahasiswa. Ringkasan hasil uji normalitas data disajikan pada Tabel 5 dan 6.

Tabel 5. Ringkasan Hasil Uji Normalitas Data Media Pembelajaran

\begin{tabular}{lccc}
\hline & Shapiro-Wilk & & \\
Variabel & Statistic & df & Sig. \\
\hline Google Classroom & 0,952 & 36 & 0,122 \\
Mobile Learning & 0,953 & 32 & 0,178 \\
\hline
\end{tabular}

Tabel 6. Ringkasan Hasil Uji Normalitas Data Kemampuan Bekerja sama

\begin{tabular}{|c|c|c|c|c|c|}
\hline \multicolumn{6}{|c|}{ Shapiro-Wilk } \\
\hline \multicolumn{3}{|c|}{ Variabel } & Statistic & $\mathrm{df}$ & Sig. \\
\hline \multicolumn{3}{|c|}{$\begin{array}{c}\text { Kemampuan Bekerja sama } \\
\text { Rendah }\end{array}$} & 0,920 & 19 & 0,115 \\
\hline $\begin{array}{l}\text { Kemampuan } \\
\text { Sedang }\end{array}$ & Bekerja & sama & 0,953 & 34 & 0,147 \\
\hline $\begin{array}{l}\text { Kemampuan } \\
\text { Tinggi }\end{array}$ & Bekerja & sama & 0,904 & 15 & 0,108 \\
\hline
\end{tabular}

Berdasarkan Tabel 5 dan 6 dapat diketahui bahwa nilai Sig. Untuk semua kelompok data lebih besar dari 0,05 sehingga dapat disimpulkan bahwa semua data pada kelompok media pembelajaran dan kemampuan bekerja sama mahasiswa berdistribusi normal. Selanjutnya dilakukan uji homogenitas data. Uji homogenitas data dilakukan dengan menggunakan uji Levene test. Ringkasan hasil uji homogenitas data disajikan pada Tabel 7.

Tabel 7. Uji Homogenitas

\begin{tabular}{cccc}
\hline $\mathrm{F}$ & $\mathrm{dk} 1$ & $\mathrm{dk} 2$ & Sig. \\
\hline 1,767 & 5 & 62 & 0,133 \\
\hline
\end{tabular}

Dari Tabel 5 dapat diketahui nilai Sig sebesar 0,133>0,05 sehingga dapat disimpulkan bahwa variansi data bersifat homogen. Setelah dilakukan uji prasyarat analisis variansi yaitu uji normalitas dan uji homogenitas dan diperoleh hasil bahwa semua populasi berdistribusi normal dan homogen, maka dapat dilakukan analisis variansi. Analisis variansi (ANAVA) digunakan untuk mengetahui signifikansi perbedaan prestasi belajar mahasiswa pada masing-masing kelompok berdasarkan kelompok media pembelajaran dan kemampuan bekerja sama mahasiswa. Uji analisis variansi yang digunakan adalah uji ANAVA dua jalan dengan sel tak sama karena

Copyright (C) 2020

\section{Buana Matematika :}

Jurnal Ilmiah Matematika dan Pendidikan Matematika 
setiap kelompok memiliki jumlah data yang berbeda. Hasil uji ANAVA Dua Jalan Sel Tak Sama data dengan menggunakan software SPSS disajikan pada Tabel 8.

Tabel 8. Hasil Uji ANAVA Dua Jalan dengan Sel Sama

\begin{tabular}{lccccc}
\hline Sumber & JK & dk & RK & F & Sig. \\
\hline Media Pembelajaran & 403,683 & 1 & 403,68 & 14,301 & 0,000 \\
Kemampuan Bekerja & 1425,111 & 2 & 3 & 25,244 & 0,000 \\
Sama & 10,716 & 2 & 712,55 & 0,190 & 0,828 \\
Interaksi & 1750,090 & 62 & 6 & & \\
Eror & & & 5,358 & & \\
& & & 28,227 & & \\
Total & 398822 & 68 & & & \\
\hline
\end{tabular}

Dari Tabel 8, diperoleh nilai probabilitas untuk kelompok media pembelajaran sebesar F = 14,301dengan nilai Sig. $=0 ., 000<0.05$, sehingga dapat disimpulkan bahwa terdapat perbedaan yang signifikan prestasi belajar mahasiswa dengan menggunakan media mobile learning dan google classroom. Rata-rata prestasi belajar matematika mahasiswa dengan menggunakan media mobile learning sebesar 80,72 sedangkan rata-rata prestasi belajar matematika mahasiswa dengan menggunakan media google classroom sebesar 72,03. Hal ini berarti prestasi belajar matematika mahasiswa dengan menggunakan media mobile learning lebih baik dibandingkan dengan prestasi belajar matematika mahasiswa dengan menggunakan media google classroom. Hal tersebut sejalan dengan penelitian yang menyatakan keefektifitasan dari model pembelajaran berbasis Mobile Learning (Drigas \& Pappas, 2015; Etcuban \& Pantinople, 2018; Luna-Nevarez \& McGovern, 2018; Skillen, 2015; Sunandar, Buchori, Rahmawati, \& Kusdaryani, 2017)

Selanjutnya, pada Tabel 8 diperoleh nilai probabilitas untuk kemampuan bekerja sama sebesar F=25,244 dengan Sig =0,000 0,05 sehingga dapat disimpulkan bahwa terdapat perbedaan yang signifikan prestasi belajar mahasiswa pada tiap tingkat kemampuan bekerja sama. Dari tabel 4 dapat diketahui, rata-rata prestasi belajar matematika mahasiswa dengan kemampuan bekerja sama tinggi memiliki sebesar 86,27, kemampuan bekerja sama sedang sebesar 75,85 dan kemampuan bekerja sama rendah sebesar 68,58 . Hal ini menunjukkan bahwa tingkat kemampuan bekerja sama memberikan efek yang berbeda terhadap prestasi belajar matematika mahasiswa. Hasil ini sejalan dengan hasil penelitian yang menyatakan bahwa 
kemampuan bekerja sama memberikan efek berbeda terhadap prestasi belajar matematika siswa (Anggraini, 2014; Marcella et al., 2018).

Hasil uji ANAVA terakhir pada Tabel 8 diperoleh nilai probabilitas untuk interaksi sebesar $\mathrm{F}=0,19$ dengan nilai Sig. $=0,828>0,05$ sehingga dapat disimpulkan bahwa tidak terdapat interaksi yang signifikan antara media pembelajaran dengan kemampuan bekerja sama mahasiswa pada pembelajaran Kalkulus Integral materi Integral. Hal ini berarti mahasiswa pada semua tingkat kemampuan bekerja sama dengan media pembelajaran mobile learning dan google classroom memberikan pengaruh yang sama terhadap prestasi belajar matematika mahasiswa. Pengaruh penggunaan media pembelajaran mobile learning dan google classroom terhadap prestasi belajar tidak bergantung kepada kemampuan kerjasama mahasiswa. Sebaliknya pengaruh kemampuan kerjasama mahasiswa, terhadap prestasi belajar tidak bergantung kepada penggunaan media pembelajaran, baik melalui mobile learning atau google classroom. Hal ini dimungkinkan karena penelitian ini belum bisa mengontrol semua variabel yang dapat mempengaruhi prestasi belajar mahasiswa. Hasil penelitian ini sejalan dengan hasil penelitian yang menyatakan bahwa siswa yang diajar menggunakan model pembelajaran yang berbeda memberikan prestasi belajar matematika yang sama pada setiap tingkat kemampuan bebekerja sama (Anggraini, 2014).

\section{Simpulan}

Berdasarkan diskusi yang telah dilakukan dapat disimpulkan bahwa: (1) pembelajaran dengan media Mobile Learning lebih efektif daripada pembelajaran dengan media Google Classroom, (2) tingkat kemampuan bekerja sama tinggi,sedang dan rendah memberikan efek yang berbeda terhadap prestasi belajar matematika mahasiswa dan (3) pengaruh penggunaan media pembelajaran mobile learning dan google classroom terhadap prestasi belajar tidak bergantung kepada kemampuan kerjasama mahasiswa. Sebaliknya pengaruh kemampuan kerjasama mahasiswa, terhadap prestasi belajar tidak bergantung kepada penggunaan media pembelajaran, baik melalui mobile learning atau google classroom.

\section{Daftar Pustaka}

Anggraini, N. E. (2014). Eksperimentasi Model Pembelajaran Think Pair Share (TPS) dengan Guided Note Talking (GNT) Pada Materi Persamaan Garis Lurus Ditinjau Dari Kemampun Bekerja Sama Siswa Kelas VIII SMP/MTs Negeri di Kota Surakarta Tahun Pelajaran 2013/2014. Jurnal Elektronik Pembelajaran Matematika, 2(4), 389-398.

Copyright (C) 2020

\section{Buana Matematika :}

Jurnal Ilmiah Matematika dan Pendidikan Matematika 
Anton, J., Kusno, K., \& Fitrianto, E. (2013). Aktivitas Kerjasama Mahasiswa Dalam Pembelajaran Kooperatif Mata Kuliah Dasar Proses Pembelajaran Matematika Melalui. Seminar Nasional Matematika Dan Pendidikan Matematika FMIPA UNY Yogyakarta, (November), 978-979.

Atikasari, G., Agoestanto, A., \& Winanti, K. (2018). Meningkatkan berpikir kreatif matematis dan kerjasama melalui model pembelajaran kooperatif strategi TTW berbantuan kartu soal materi trigonometri SMAN 5 Semarang. In Prisma (Vol. 1, pp. 601-607).

Attwell, G. (2010). Work-Based Mobile Learning Environments: Contributing to a Socio-Cultural Ecology of Mobile Learning. International Journal of Mobile and Blended Learning. https://doi.org/10.4018/jmbl.2010100102

Drigas, A. S., \& Pappas, M. A. (2015). A review of mobile learning applications for mathematics. International Journal of Interactive Mobile Technologies, 9(3), 18-23. https://doi.org/10.3991/ijim.v9i3.4420

Etcuban, J. O., \& Pantinople, L. D. (2018). The Effects of Mobile Application in Teaching High School Mathematics. International Electronic Journal of Mathematics Education, 13(3), 249-259. https://doi.org/10.12973/iejme/3906

Luna-Nevarez, C., \& McGovern, E. (2018). On the Use of Mobile Apps in Education: The Impact of Digital Magazines on Student Learning. Journal of Educational Technology Systems, 47(1), 17-31. https://doi.org/10.1177/0047239518778514

Maasawet, E. T. (2011). Meningkatkan Kemampuan Kerjasama Belajar Biologi Melalui Penerapan Strategi Inkuiri Terbimbing Pada Siswa Kelas Vii Smp Negeri Vi Kota Samarinda Tahun Pelajaran 2010/ 2011. BIOEDUKASI (Jurnal Pendidikan Biologi). https://doi.org/10.24127/bioedukasi.v2i1.197

Marcella, A., Wulanata, I. A., \& Listiani, T. (2018). Penerapan Team Quiz Untuk Meningkatkan Kemampuan Kerja Sama Antar Siswa Kelas Viii-B Pada Mata Pelajaran Matematika [the Implementation of a Team Quiz To Improve Cooperation Skills Among Grade 8B Students in Mathematics]. JOHME: Journal of Holistic Mathematics Education, 1(2), 124. https://doi.org/10.19166/johme.v1i2.799

Nugroho, A. A., \& Purwati, H. (2015). Pengembangan Media Pembelajaran Matematika Berbasis Mobile Learning Dengan Pendekatan Scientific. Copyright $(02020$

Buana Matematika :

Jurnal Ilmiah Matematika dan Pendidikan Matematika 
Euclid, 2(1), 174-182. https://doi.org/10.33603/e.v2i1.355

Nuryadi, N. (2019). Pengembangan Media Matematika Virtual Berbasis Teams Game Tournament ditinjau dari Kemampuan Pemecahan Masalah. JIPM (Jurnal Ilmiah Pendidikan Matematika), 7(2), 114. https://doi.org/10.25273/jipm.v7i2.3656

Pratiwi, I. A., Ardianti, S. D., \& Kanzunnudin, M. (2018). Peningkatan Kemampuan Kerjasama Melalui Model Project Based Learning (Pjbl) Berbantuan Metode Edutainment Pada Mata Pelajaran Ilmu Pengetahuan Sosial. Refleksi Edukatika : Jurnal Ilmiah Kependidikan, 8(2). https://doi.org/10.24176/re.v8i2.2357

Ramadan, F. A., \& Arfinanti, N. (2019). Pengembangan Mobile Learning RENSI (Relasi dan Fungsi) Berbasis Android pada Pokok Bahasan Relasi dan Fungsi sebagai Sumber Belajar Mandiri Siswa Kelas VIII SMP. Jurnal Pengembangan Pembelajaran Matematika (JPPM). https://doi.org/10.21240/mpaed/XX/2014.03.03.X

Setyadi, D. (2017). Pengembangan Mobile Learning Berbasis Android Sebagai Sarana Berlatih Mengerjakan Soal Matematika. Satya Widya, 33(2), 87-92. https://doi.org/10.24246/j.sw.2017.v33.i2.p87-92

Skillen, M. A. (2015). Mobile Learning : Impacts on Mathematics Education. Proceedings of the 20th Asian Technology Conference in Mathematics (Leshan, China, 2015) Mobile, 205-214.

Suhardi. (2013). Peningkatan Partisipasi dan Kerjasama Siswa Menggunakan Model Kooperatif Tipe Jigsaw pada Materi Protozoa Kelas X SMA N Pengasih. Jurnal Pendidikan Matematika Dan Sains Tahun, 1(2), 140-146. https://doi.org/10.21831/jpms.v2i2.2482

Sunandar, Buchori, A., Rahmawati, N. D., \& Kusdaryani, W. (2017). Mobilemath (mobile learning math) media design with seamless learning model on analytical geometry course. International Journal of Applied Engineering Research, 12(19), 8076-8081.

Wulandari, B., Arifin, F., \& Irmawati, D. (2015). Peningkatan Kemampuan Kerjasama dalam Tim Melalui Pembelajaran Berbasis Lesson Study. Elinvo (Electronics, Informatics, and Vocational Education), 1(1), 9-16. https://doi.org/10.21831/elinvo.v1i1.12816

Copyright (C) 2020

Buana Matematika :

Jurnal Ilmiah Matematika dan Pendidikan Matematika 
Yuliani, R. E. (2010). Pengembangan Mobile Learning (M-Learning) Sebagai Model Pembelajaran Alternatif Dalam Meningkatkan Minat Dan Kemampuan Siswa Terhadap Matematika. Jurnal Pendidikan MIPA, 1(1), 52-61.

\section{Riwayat Hidup Penulis}

\section{Siti Suprihatiningsih}

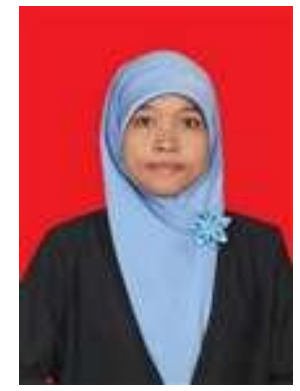

Lahir di Boyolali, 17 November 1987. Staf pengajar di STKIP Pamane Talino. Studi S1 Pendidikan Matematika UIN Sunan Kalijaga, Yogyakarta, lulus tahun 2011; S2 Pendidikan Matematika Universitas Sebelas Maret, Surakarta, lulus tahun 2014. Pengembangan Modul Matematika Berbasis Masalah Pada Materi Sistem Persamaan Linear Dua Variabel.

\section{Nugroho Arif Sudibyo}

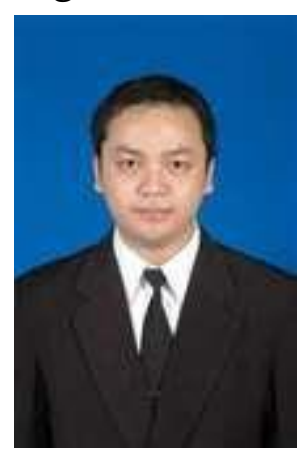

Lahir di Boyolali, 26 Januari 1989. Staf pengajar pada program studi Teknik Informatika Universitas Duta Bangsa. Studi S1 Matematika Universitas niversitas Sebelas Maret, Surakarta, lulus tahun 2011; S2 Pendidikan Matematika Universitas Sebelas Maret, Surakarta, lulus tahun 2014. Pada tahun 2018 menerima hibah penelitian dari Kemenristekdikti dengan judul Pelabelan Total Tak Regular Pada Graf Barbel, Graf Caveman dan Graf Crown sebagai ketua dan Pengembangan Kelas Semu Menggunakan Google Classroom Berbasis Framework RAD (Rapid Application Development) sebagai anggota.

\section{Triana Harmini}

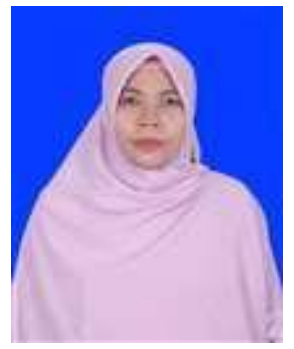

Lahir di Ponorogo, 17 Januari 1985. Staf pengajar pada program studi Teknik Informatika Universitas Darussalam Gontor. Studi S1 Pendidikan Matematika Universitas Negeri Malang, lulus tahun 2007; S2 Pendidikan Matematika Universitas Sebelas Maret, Surakarta, lulus tahun 2014. Pada tahun 2018 menerima hibah penelitian dari Kemenristekdikti dengan judul Pengembangan Modul Pembelajaran berbasis Differentiated Instruction Pada Mata Kuliah Kalkulus.

Copyright (C) 2020

Buana Matematika :

Jurnal Ilmiah Matematika dan Pendidikan Matematika 